\title{
Urgensi Manajemen Kerjasama Universitas Muhammadiyah Mataram Dengan Asia Muslim Charity Fondation (AMCF)Dalam Pengembangan Universitas Muhammadiyah Mataram
}

\author{
Marzoan \\ Alumni Pascasarjana Universitas Islam Negeri Mataram \\ Jl. Gajah Mada Mataram \\ Korespondensi Penulis: joanI09@yahoo.co.id
}

\begin{abstract}
ABSTRAK
Kata Kunci: Manajemen, Kerjasama, Pengembangan

Universitas Muhammadiyah Mataram merupakan lembaga Perguruan Tinggi Islam yang memiliki Visi untuk menjadi Universitas yang Islami, mandiri, unggul dan berdaya saing di kawasan ASEAN, Salah satu langkah yang diambil adalah menjalin kerjasama dengan $A M C F$. Tujuan penelitian ini adalah: (I) Untuk memahami manajemen kerjasama Universitas Muhammadiyah Mataram dengan $A M C F$ dalam Pengembangan Universitas Muhammadiyah Mataram (2) Untuk memahami bentuk kerjasama Universitas Muhammadiyah Mataram dengan $A M C F$ dalam Pengembangan Universitas Muhammadiyah Mataram (3) Untuk memahami dampak kerjasama Universitas Muhammadiyah Mataram dengan $A M C F$ dalam Pengembangan Universitas Muhammadiyah Mataram. Penelitian ini menggunakan pendekatan kualitatif, Pengumpulan data menggunakan metode wawancara, observasi, dan dokumentasi. Tehnik analisis data menggunakan reduksi data, penyajian data, dan penarikan kesimpulan. Pengecekan keabsahan temuan menggunakan ketekunan pengamatan, dan triangulasi. Hasil penelitian ini adalah (I) Kerjasama Universitas Muhammadiyah Mataram Dengan Asia Muslim Charity Fondation (AMCF) dikembangkan dalam bidang dakwah, pendidikan dan kesehatan. (2) Bentuk kerjasama Universitas Muhammadiyah Mataram Dengan Asia Muslim Charity Fondation $(A M C F)$ adalah (a) Beasiswa dan Biaya Oprasional berupa biaya kuliyah dan Asrama gratis serta biaya oprasional untuk kegiatan dan pengembangan mahad Khalid bin Walid dan Program Studi KPI (b) Penyelenggaraan Pendidikan, berupa kegiatan pembelajaran di Ma'had yang dilakukan selama 2 tahun dan perkuliyahan pada Program Studi KPI (c) Pemberdayaan Alumni, berupa prekrutan alumni sebagai Da'i dan diberikan tunjangan setiap bulannya oleh AMCF, dan (d) Pengembangan Sumber Daya Manusia (SDM), berupa pengkaderan bahasa arab, bidang penelitian, pengabdian dan pengajaran bagi dosen dan karyawan. (3) dampak kerjasama ini adalah Meningkatnya jumlah mahasiswa, meningkatnya jumlah sarana dan prasarana berupa asrama, gedung Ma'had, gedung perkuliyahan, kelinik, masjid dan mobil ambulance, dan Meningkatnya kualitas Sumber Daya Manusia (SDM) yang tercermin dari kemampuan dosen dalam berbahasa arab, melakukan pengabdian dan penelitian.
\end{abstract}




\section{Pendahuluan}

Universitas Muhammadiyah Mataram merupakan lembaga perguruan tinggi Islam yang memmiliki Visi untuk menjadi Universitas yang Islami, mandiri, unggul dan berdaya saing di kawasan ASEAN. Untuk mewujudkan Visi tersebut, Universitas Muhammadiyah Mataram menyelenggarakan "catur darma perguruan tinggi, pendidikan tinggi yang mandiri, membentuk insan civitas akademik yang berakhlak mulia dan menjunjung tinggi nilai-nilai Islam, pengeleolaan universitas yang profesional, akuntabel dan amanah, serta membangun kerjasama, ditingkat Nasional, Regional maupun Internasional yang saling menguntungkan. Salah satu bentuk pengembangan Universitas Muhhamdiyah Mataram yang sangat berpengaruh adalah dengan melakukan kerjasama dengan intansi luar negeri, diantaranya kerjasama dengan: (I) Asia Muslim Charity Fondation (AMCF) (2) Universitas Kebangsaan Malaysia (UKM) (3) Universitas Sains Islam Malaysia (USIM) (4) Universitas Teknologi Malaysia (UTM) (5) Universitas Malaya (UM) dan beberapa Perguruan Tinggi Luar Negeri. Asia Muslim Charity Fondation (AMCF) adalah organisasi social non profit dan non politik, yayasan ini sudah berjalan sejak tahun 1992 dan didirikan di Jakarta sejak Tahun 2002. AMCF berkiprah dalam kegiatan sosial, dakwah, kesehatan, dan pendidikan. Adapun programnya adalah pembangunan masjid, pembangunan sarana pendidikan, pembangunan panti asuhan dan rumah du'afa, pembangunan taman kanakkanak, mendirikan asrama bagi mahasiswa, mendirikan sarana kesehatan berupa rumah sakit dan klinik bersalin, dan lain-lain. Untuk mengetahui Bentuk kerjasama $A M C F$ dengan Universitas Muhammadiyah Mataram dalam pengembangan Universitas Muhammadiyah Mataram maka peneliti tertarik untuk melakukan sebuah penelitian tentang "Manajemen Kerjasama Universitas Muhammadiyah Mataram Dengan Asia Muslim Charity Fondation (AMCF)Dalam Pengembangan Universitas Muhammadiyah Mataram". Adapun rumusan masalah penelitian ini adalah sebagai berikut: (I) Bagaimana manajemen kerjasama Universitas Muhammadiyah Mataram Dengan Asia Muslim Charity Fondation (AMCF) dalam Pengembangan Universitas Muhammadiyah Mataram? (2) Bagaimana bentuk kerjasama Universitas Muhammadiyah Mataram Dengan Asia Muslim Charity Fondation (AMCF) dalam Pengembangan Universitas Muhammadiyah Mataram? (3) Bagaimana dampak kerjasama Universitas Muhammadiyah Mataram dengan Asia Muslim Charity Fondation (AMCF) dalam Pengembangan Universitas Muhammadiyah Mataram?. Adapun kontribusi penelitian ini adalah : (I) Untuk memahami manajemen kerjasama Universitas Muhammadiyah Mataram dengan Asia Muslim Charity Fondation (AMCF) dalam Pengembangan Universitas Muhammadiyah Mataram. (2) Untuk memahami bentuk kerjasama Universitas Muhammadiyah Mataram dengan Asia Muslim Charity Fondation (AMCF) dalam Pengembangan Universitas Muhammadiyah Mataram. (3) Untuk memahami dampak kerjasama Universitas Muhammadiyah Mataram dengan Asia Muslim Charity Fondation (AMCF) dalam Pengembangan Universitas Muhammadiyah Mataram. kontribusi

\section{Metode}

Penelitian ini menggunakan pendekatan kualitatif. Jenis penelitian yang digunakan adalah studi kasus eksplanatoris, dimana penelitian ini mencari penjelasan berbagai pristiwa yang berbeda ataupun yang sama serta melihat secara lebih mendalam segala penomena yang terjadi pada obyek penelitian. kehadiran peneliti dipandang penting dan menentukan atas keberhasilan peneliti sebagai instrumen kunci yang berusaha menyesuaikan diri dengan situasi dan kondisi yang ada di lapangan, serta hubungan yang harmonis dengan informasi kunci yang terkait dengan penelitian. Hubungan baik tersebut dapat membangun emosional, saling pengertian dan adanya kepercayaan terhadap peneliti, semua itu dilakukan sehingga dapat memperoleh datadata yang akurat. Adapun lokasi penelitian yang telah dilakukan adalah di Universitas 
Muhammadiyah Mataram, karena Universitas Muhammadiyah Mataram telah banyak memperoleh kontribusi dalam pengembangan, perubahan dan perbaikan Universitas Muhammadiyah Mataram melaui kerjasama dengan berbagai perguruan Tinggi dan lemabaga lainnya baik di dalam maupun luar Negeri terutama kerjasama dengan Asia Muslim Carity Pondation (AMCF). Adapun yang menjadi sumber data dalam penelitian ini adalah ketua Kantor Urusan Internasional (KUI) Universitas Muhammadiyah Mataram, Direktur, sekretaris dan bendahara Ma'had Khalid bin Walid Universitas Muhammadiyah Mataram, Dekan serta Kaprodi KPI Fakultas Agama Islam (FAI) Universitas Muhammadiyah Mataram, Dosen Program Studi Komunikasi Penyiaran Islam (KPI) dan Mahasiswa Program Studi Komunikasi Penyiaran Islam (KPI). Teknik pengumpulan data dalam penelitian ini adalah: (I) wawancara semiterstrukur, (2) observasi, (3) studi dokumen. Pada tahap reduksi data, peneliti telah melakukan pemilahan data, kemudian menggolongkan, dan mengarahkan serta membuang data yang tidak perlu, langkahlangkah selanjutnya yang dilakukan dalam mereduksi data antara lain sebagai berikut: (a) Membuat ringkasan mengenai data yang sudah diberi warna sesuai dengan sub fokus penelitian dan mengembangkan kategori pengkodean. (b) Meberikan kode pada setiap data yang diperoleh baik melalui wawancara, obsevasi maupun dokumantasi. (c) Menyortir data. Dalam kegiatan reduksi data, penyortiran data merupakan langkah terakhir. Penyajian data dilakukan setelah melakukan pemilahan data sesuai dengan rumusan masalah yang sudah ditentukan, kemudian disusun berdasarkan urutan rumusan masalah sehingga tidak terjadi kerancuan data yang terlalu luas atau kerancuan karena ketidak sesuaian isi data dengan rumusan penelitian. Pengujian terhadap kredibilitas data dalam penelitian ini dilakukan dengan triangulasi sumber data dan triangulasi metode, serta membercheck. Triangulasi dilakukan dengan membandingkan dan mengecek balik derajat kepercayaan suatu informasi yang diperoleh dari informan yang satu dengan informan lainnya.

\section{Hasil dan Pembahasan}

A. Manajemen Kerjasama Universitas Muhammadiyah Mataram Dengan Asia Muslim Charity Fondation (AMCF) Dalam Pengembangan Universitas Muhammadiyah Mataram

Kerjasama Universitas Muhammadiyah Mataram dengan Asia Muslim Charity Fondation (AMCF) secara umum menjalin kerjasama dalam bidang dakwah, pendidikan dan kesehatan. kerjasama dalam bidang dakwah menjadi dasar terjalinnya kerjasama dan dikembangkan melalui pengkaderan da'i yang dilakukan di ma'had khalid bin walid Universitas Muhammadiyah Mataram, kerjasama dalam bidang pendidikan dilakukan dengan didirikannya sebuah program studi yang dibiayai sepenuhnya oleh AMCF, kerjasama dalam bidang kesehatan dilakukan dengan didirikannya kelinik kesehatan Universitas Muhammadiyah Mataram. Hal ini menunjukkan bahwa kerjasama yang dibangun oleh Universitas Muhammadiyah Mataram dengan AMCF memberikan pengembangan Universitas Muhammadiyah Mataram kearah yang lebih baik hal sebagai tujuan utama dilakukannya kerjasama dalam pengembangan Universitas sebagaimana yang dikatakan oleh Muhadjir Efendi "Menjalin kerjasama dengan instansi lain adalah hal yang tidak bisa dihindari dalam pengembanagan Perguruan Tinggi, karena kerjasama merupakan langkah yang tepat untuk saling memasuki serta melengkapi untuk terus saling mempelajari dalam rangka membangun Perguruan Tinggi yang berkulitas. Perkembangan teknologi saat ini memberikan peluang yang besar untuk menjalian kerjasama dengan berbagai Perguruan Tinggi atau instansi-instansi lainnya" ${ }^{58}$. Kerjasama menciptakan keunggulan tersendiri bagi Universitas Muhammadiyah Mataram dimana mahasiswa secara mendapatkan bimbingan sebagai da’i yang secara terus menerus mengkaji keislaman dari berbagai sumber dan pengembangan bahasa hususnya

${ }^{58}$ Muhadjir Effendy, Seminar dan Lokakarya Nasional Manajemen Perguruan Tinggi Masa Depan untuk Meningkatkan Daya Saing Bangsa- Dirjen Dikti Depdiknas pada tanggal 26-28 April 2006 di Pekanbaru, Riau. 
bahasa arab yang dilakukan selama dua tahun di ma'had khalid bin Walid. Hal ini sesuai dengan strategi pengembangan Perguruan Tinggi dimana setiap lembaga harus memiliki keunggulan tersendiri agar kepercayaan stace holder tetap terjaga, sebagaiman yang di katakan oleh Muhajir. "Membangun competitive advance centres atau pusat keunggulan diberbagai bidang di Perguruan Tinggi dapat membentuk brand imagedi mata masyarakat sehingga terbangunlah kepercayaan pengguna lulusan terhadap perkembangan Perguruan Tinggi yang berkemajuan. Adapun strategi yang dapat digunakan dalam pembangunan dan pengembangan keunggulan ini salah satunya adalah Strategi USE PDSA. Pengembangan bidang ini dilakukan suatu perbaikan yang terus menerus, sehingga tugas tugas pokok pimpinan adalah mengadakan perbaikan proses yang terjadi secara berkesinambungan. Adapun yang dimaksud dengan USE PDSA adalah sebagai berikut Understand improvement needs (mengerti kebutuhan perbaikan), State the problem (Temukan masalahnya), Evaluate the root Cause(menemukan akar permasalahannya), Plan the solution(merencanakan solusinya), end Do or implement the solution (mengimpelemntasikan solusi tersebut)" 59

\section{B. Bentuk kerjasama Universitas Muhammadiyah Mataram Dengan Asia Muslim Charity Fondation (AMCF) dalam Pengembangan Universitas Muhammadiyah Mataram.}

Bentuk kerjasama Universitas Muhammadiyah Mataram Dengan Asia Muslim Charity Fondation (AMCF) dalam Pengembangan Universitas Muhammadiyah Mataram meliputi beasiswa dan biaya oprasional, penyelenggaraan pendidikan, pemberdayaan alumni,. dan pengembangan sumber daya manusia (SDM).

I. Beasiswa dan Biaya Oprasional.

Sumber dana penyelenggaraan perguruan tinggi pada umumnya bersumber dari APBD dan mahasiswa ,sehingga serigkali
${ }^{59}$ Muhadjir Effendy, Seminar dan Lokakarya penyelenggaraan pendidikan yang lebih berkualitas dihadapkan dengan kurangnya biaya pendidikan yang berdampak pada kurang terpenuhinya sarana prasarana ataupun mutu pendidikan tersebut. Terlebih dengan banyaknya mahasiswa yang berlatarbelakang ekonomi menengah kebawah menyebabkan banyaknya mahasiswa yang putus ditengah jalan yang disebabkan karena keterbatasan biaya perkuliyahan. Hal itu memang tidak bisa dipungkiri sebagaimana yang dikatakan oleh Syahrizal Abbas " Dalam kenyatannya penggalian sumber pendanaan Perguruan Tinggi, umumnya lebih banyak mengandalkan dana SPP Mahasiswa, terutama dari Perguruan Tiggi swasta" ${ }^{60}$. Jika sebuah perguruan tinggi hanya mengandalkan SPP mahasiswa tentunya ini akaan memberatkan beban bagi mahasiswa atau stace holder, sehingga jalan yang harus di ambil oleh Perguruan tInggi adalah dengan mencari sumber dana lain yang hal ini hanya bisa dibangun melalui kerjasama dengan berbagai instansi. Sehubungan dengan hal tersebut Sahrizal Abbas juga menjelaskan "Untuk pengengembangan Perguruan Tinggi kedepan, tidak cukup hnaya mengandalkan SPP mahasiswa. SPP mahasiswa tidak akan mampu menjamin kekuatan Perguruan Tinggi dalam meningkatkan kualitas dan daya saingnya. Oleh karena itu diperlukan penggalian sumbersumber dana baru bagi Perguruan Tinggi yang dapat menjamin keberlangsungan aktivitas Perguruan Tinggi" ${ }^{61}$. Melihat hal di atas, amka langkah yang diambil oleh Universitas Muhammadiyah mataram sangat tepat, dimana kerjasama yang dibangun memberikan suntikan dana dalam pengembangan Universitas Muhammadiyah Mataram dalam berbagai bidang yang merupakan bentuk kerjasama Universitas Muhammadiyah Mataram dengan AMCF yaitu dengan diberikannya beasiswa dan biaya oprasional serta asrama geratis bagi mahasiswa.

2. Penyelenggaraan Pendidikan

Salah satu bentuk kerjasama Universitas Muhammadiyah Mataram dengan AMCF Tinggi, I62.

${ }^{60}$ Sahrizal Abbas, Manajemen Perguruan Tinggi, I62.

${ }^{6 I}$ Sahrizal Abbas, Manajemen Perguruan 
adalah Penyelenggaraan Perguruan Tinggi, diamna AMCF mebiayai sepenuhnya salah satu program studi yang ada dibawah naungan Universitas Muhammadiyah mataram. AMCF sebagai salah satu organisasi yang ikut membangun lembaga Perguruan Tinggi, Dimana AMCF ikut terlibat dalam berbagai hal dalam berbagai hal diantaranya sumbangan berupa bangunan yang sepenuhnya menjadi hak Universitas Muahmmadiyah mataram, hal itu sesui dengan yang dijelaskan oleh Sahrizal Abbas bahwa" hak perguruan tinggi sebagai badan hukum antara laian, boleh mendirikan mendirikan badan usaha, memiliki aset, memiliki bangunan, memiliki tanah, dan sebaginya dalam batas yang telah diatur oleh Undang-Undang" ${ }^{2}$

3. Pengembangan Sumber Daya Manusia (SDM)

Salah satu aspek penunjang yang sangat penting dalam membangaun sebuah universitas adalah membangun sumber daya manusia yang berkualitas baik dari segi dosen ataupun tenaga kependidikannya. Dosen yang berkualitas setidaknya memiliki kompetensi profesional, kompetensi pedagogik, kompetensi sosial dan kompetensi kepribadian yang mana hal itu ditunjukkan dengan kemampuan dosen dalam mengamalkan tri darma perguruan tinggi yang dikembangkan dalam Universitas Muhammadiyah Mataram menjadi catur darma perguruan tinggi yang meliputi (I) Al-Islam Kemuhammadiyahan (2) Kegiatan Belajar Mengajar (2) Penelitian, dan (3) Pengabdian Kepada Masyarakat. Kemampuan ini hendaknya ditunjang dengan berbagai kegiatan yang mendukung terlaksananya catur darma perguruan tinggi tersebut. Pengembangan SDM merupakan hal yang sangat penting dalam pengembangan perguruan tinggi sebagaimana yang dikatakan oleh Muhajir Efendi tentang salah satu strategi pengembangan Perguruan Tinggi adalah "Membangun profesionalisme, menjamin kualitas dan menjaga hubungan baik dengan stakeholder. Kegiatan ini merupakan sebuah strategi yang sangat penting dalam membangun Perguruan Tinggi, kualitas yang baik harus ditunjang dengan sumber daya

Tinggi, 96. manusia (SDM) yang profesional serta mampu untuk menjalin komunikasi yang baik dengan pengguna lulusan atau stakeholder karena keterlibatan pengguna lulusan sangatlah penting dalam menciptakan lulusan yang berkualitas" ${ }_{63}$

\section{Dampak kerjasama Universitas Muhammadiyah Mataram dengan Asia Muslim Charity Fondation (AMCF)dalam Pengembangan Universitas Muhammadiyah Mataram}

Pembangunan kerjasama Universitas Muhammadiyah Mataram dengan Asia Muslim Charity Fondation (AMCF) dalam bentuk beasiswa dan biaya oprasional yang ditanggung oleh AMCF memiliki dampak yang cukup besar terhadap perkembangan Universitas Muhammadiyah Mataram hususnya pengembangan Program Studi KPI Fakultas Agama Islam Universitas Muhammadiyah Mataram. Secara umum ada beberapa komponen yang menjadi dampak beasiswa dan biaya oprasional yaituPertama Adanya beasiswa berupa asrama dan biaya kuliyah geratis berpengaruh terhadap jumlah Mahasiswa Fakultas Agama Islam Universitas Muhammadiyah Mataram, hal itu dapat dilihat dari bertambahnya jumlah mahsiswa yang yang mendaftarkan diri pada Fakultas Agama Islam Hususnya Program Studi Komunukasi dan Penyiaran Islam setiap tahunnya. Kedua kerjasama tersebut berdampak pada pengembangan sarana prasarana berupa sarana pembelajaran, sarana kesehatan, sarana ibadah berupa masjid. Ketiga Mahasiswa secara tidak langsung melalui program dakwah akan melakukan sosialisasi atau pengenalan Fakultas Agama Islam dan atau Universitas Muhammadiyah Mataram pada umumnya, hal ini dilakukan dalam program dakwah yang dilakukan oleh santri mah'had selama satu tahun. Hal ini sesuai dengan manfaat kerjasama yaitu sebagai berikut: (I) Meningkatkan kualitas pendidikan sehingga setara dengan kualitas pendidikan internasional, (2) Meningkatkan kualitas penelitian sehingga

${ }^{63}$ Muhajir Efendi, Muhadjir Effendy, Seminar dan Lokakarya Nasional Manajemen Perguruan Tinggi Masa Depan untuk Meningkatkan Daya Saing BangsaDirjen Dikti Depdiknas pada tanggal 26-28 April 2006 di Pekanbaru, Riau. 
hasil-hasil penelitian dapat diakui dunia internasional, (3) Meningkatkan kompetensi dan kapasitas staf akademik dan peneliti, (4) Meningkatkan kompetensi dan kapasitas lulusan, (5) Meningkatkan reputasi universitas di mata dunia internasional dan mendapatkan keuntungan finansial dengan datangnya mahasiswa asing serta penggunaan hasil-hasil penelitian.

\section{Simpulan}

Berdasarkan penelitian tersebut di atas, maka penulis menyimpulkan bahwa Manajemen Kerjasama Universitas Muhammadiyah Mataram Dengan Asia Muslim Charity Fondation (AMCF) dikembangkan dalam bidang dakwah, pendidikan dan kesehatan, yang mana lembaga pendidikan yang bernaung di bawah $A M C F$ diberikan peluang bernaung di bawah Universitas Muhammadiyah Mataram, khususnya program studi KPI, sehingga memiliki ijazah yang setara dengan SI. Sebagai bentuk dukungan, AMCF memberikan berbagai bentuk bantuan pendukung kepada Universitas Universitas Muhammadiyah Mataram, sehingga terjalinlah saling menguntungkan satu sama lain.

Adapun bentuk kerjasama Universitas Muhammadiyah Mataram Dengan Asia Muslim Charity Fondation (AMCF) adalah (I) Pemberian Beasiswa kepada mahasiswa mencakup, biaya kuliyah, asrama mahasiswa gratis serta biaya oprasional untuk kegiatan dan pengembangan ma'had Khalid bin Walid dan Program Studi KPI Universitas Muhammadiyah Mataram. (2) Penyelenggaraan Pendidikan, berupa kegiatan pembelajaran di ma'had yang dilakukan selama 2 tahun, selain perkuliyahan pada Program Studi KPI Universitas Muhammadiyah Mataram. (3) Pemberdayaan Alumni, berupa prekrutan alumni sebagai da'i yang ditempatkan pada tempat yang telah di tentukan AMCF dan diberikan tunjangan setiap bulannya oleh AMCF, dan (4) Pengembangan Sumber Daya Manusia (SDM), berupa pengkaderan Bahasa Arab, bidang penelitian, bidang pengabdian dan bidang pengajaran bagi dosen dan keryawan yang bernaung di bawah naungan AMCF.
Adapun dampak kerjasama Universitas Muhammadiyah Mataram dengan Asia Muslim Charity Fondation (AMCF) adalah Meningkatnya jumlah mahasiswa setiap angkatan yang terlihat dari jumlah mahasiswa yang mendaftar ke ma'had setiap tahunnya, Meningkatnya jumlah sarana dan prasarana berupa asrama,gedung Ma'had, gedung perkuliyahan, kelinik, masjid dan mobil ambulance. Meningkatnya sosialisai kampus yang tersebar melalui program dakwah yang dilakukan selama satu tahun, dan Meningkatnya kualitas Sumber Daya Manusia (SDM) yang tercermin dari kemampuan dosen dalam berbahasa arab, melakukan pengabdian dan penelitian serta semakin meningkatnya kualitas pembelajaran yang telah dilakukan.

\section{Referensi}

A.Koolma dan C.J.M. Van de Schoot, ,2007, Manajemen Proyek, Pedoman Untuk Mengelola dan Memimpin Serta Bekerjasama Dalam Proyek. Penerjemah:Soeheba Kramadibrata . Jakarta: Penerbit Universitas Indonesia

Abbas Sahrizal, 20I4, Manajemen Perguruan Tinggi, Jakarta: PT Kharisma Putra Utama.

Buku Pedoman Universitas Muhammadiyah Mataram, 2016-20I7

Burhan Bungin, 2007, Metodologi Penelitian Kualitatif Aktualisasi Metodologis Ke Arah Ragam Varian Kontemporer, Jakarta: PT Raja Grafindo Persada,

Damaianti dan Syamsuddin, 2006, Metode Penelitian PendidikanBandung: PT. Remaja Rosdakarya.

David, F.R, 2004, Strategic Management, Jakarta. PT. Prenhalindo.

Dikti Depdiknas pada tanggal 26-28 April 2006 di Pekanbaru, Riau.

Effendy Muhadjir, Makalah disampaikan pada acara Seminar dan Lokakarya Nasional Manajemen Perguruan Tinggi Masa Depan untuk Meningkatkan Daya Saing Bangsa- Dirjen

Emzir, 2010, Metodologi Penelitian Kualitatif, Jakarta: PT Raja Grafindo Persada 
H. Malayu Hasibuan S.P, 2004, Dasar-Dasar Perbankan, Jakarta: Bumi Aksara

Hasibuan,

2005.Dasar-dasar Manajemen, Jakarta : Bumi Aksara

Heri Daryono, 20I4, Manajemen Kerjasama Antara Sekolah Menengah Kejuruan dengan Industri ( Jurnal Educationl managemen Universitas Negeri Semarang 3 (2)

J. Panglaykim, Hazil Tanzil, I986, Manajemen, Suatu Pengantar, Jakarta Timur: Balai Aksara

Jurnal Phenomenon, Volume I Nomor I, Juli 2013

Lincol dan Guba, 1985,Metodologi Penelitian Kualitatif Bandung : PT Remaja Rosdakarya,

Manulang M., I98I, Dasar-Dasar Manajemen, Jakarta: Gajah Mada University press

Matthew B. Miles \& A. Micael Huberman, 1992, Analisis Data Kualitatif, Jakarta : Penerbit Universitas Indonesia (UIPress)

Moekijat, 1975, Administrasi Kantor , Bandung: Penerbit Alumni.

Moleong Lexy j., ,20II,Metodologi Penelitian Kualitatif Bandung: Remaja Rosda Karya

Mulyasa E., 2013, Implementasi kurikulum 2013, Bandung: PT Remaja Rosdakarya

Mulyono, 2008, Manajemen Administrasi \& Organisasi Pendidikan, Yogyakarta : Ar-Ruzz Mediya

Munir Muhammad, 2006, Manajemen Dakwah, Jakarta : Kencana

Permenristekdikti No 44 Tahun 2015 Tentang Standar Nasional Pendidikan Tinggi (SNPT).

Salinan Peraturan Mentri Pendidikan dan kebudayaan Republik Indonesia Tahun 2014

Siagian, 1983, Manajemen Pemerintahan, Jakarta : PT. Pertja.

Siswanto, HB.DR. 2007. Pengantar manajemen, Jakarta : Bumi Aksara

Sugiyono, 2012, Metode Penelitian Pendidikan Pendekatan Kuantitatif, Kualitatif, dan $R \& D$ Bandung: alfabeta

Sukanto Reksohadiprodjo 20I0, Dasar-Dasar Manajemen, Yogyakarta : BPFE
Sukmadinata Nana Syaodih, 20II, Metode Penelitian Pendidikan Bandung: PT Remaja Rosdakarya

Undang-Undang Nomor I2 Tahun 2012 Tentang Pendidikan Tinggi Pasal I ayat 2 dan 3 